\title{
Assessing the Role of Waste Pickers in the Recycling Industry in Accra Metropolis
}

\author{
I. K. Kwarteng1,2, Davor Kontič3, Tine Bizjak ${ }^{3,4}$, Branko Kontič ${ }^{3}$ \\ ${ }^{1}$ Department of Nuclear Science and Applications, Graduate School of Nuclear and Allied Sciences, University of Ghana, \\ Legon, Accra \\ ${ }^{2}$ Nuclear Chemistry and Environmental Research Centre, Ghana Atomic Energy Commission, Legon, Accra \\ ${ }^{3}$ Department of Environmental Sciences, Jožef Stefan Institute, Ljubljana, Slovenia \\ ${ }^{4}$ International Postgraduate School, Jožef Stefan Institute, Ljubljana, Slovenia \\ Email:kikme960@gmail.com
}

How to cite this paper: Kwarteng, I. K., Kontič, D., Bizjak, T., \& Kontič, B. (2020). Assessing the Role of Waste Pickers in the Recycling Industry in Accra Metropolis. Journal of Geoscience and Environment Protection, 8, 73-87.

https://doi.org/10.4236/gep.2020.810005

Received: August 21, 2020

Accepted: October 16, 2020

Published: October 19, 2020

Copyright $\odot 2020$ by author(s) and Scientific Research Publishing Inc. This work is licensed under the Creative Commons Attribution International License (CC BY 4.0).

http://creativecommons.org/licenses/by/4.0/

(c) (i) Open Access

\begin{abstract}
Despite their contributions to solving specific waste management issues by collecting recyclables, waste-pickers are maligned when waste management policies are formulated. The purpose of this study was to assess and expose the beneficial economic and environmental protection role of waste pickers and how they can be integrated into the solid waste management system. The study imposed both quantitative and qualitative data collection method (mixed method research). The primary data were sourced through face-to-face in-depth interviews with operators and managers of the dumpsites. The selected waste pickers were asked to fill a questionnaire that brought to the fore all that their work entails from the number of recyclables recovered to their occupational health and safety. Results show that the volume of waste retrieved from the waste stream at the three dumpsites in Accra metropolis is less than $1 \%$ per annum. The waste pickers, if integrated into the waste management system and motivated, could help in reviving the recycling industry which would reduce the pressure on virgin materials and the environment. It is also their source of livelihood. The benefits are mutual.
\end{abstract}

\section{Keywords}

Waste-Pickers, Solid Waste Management, Recyclables, Dumpsites, Policies

\section{Introduction}

Population growth, increased urbanisation and improvements in living standards has led to significant increases in solid waste production, making solid waste management one of the major challenges of the world today (Chabuk et 
al., 2015). In countries around the world, one major environmental problem that confronts municipal authorities is solid waste disposal (Douti et al., 2017).

Many cities in developing countries face serious environmental degradation and health risks due to the solid waste (Sankoh et al., 2013). The regions with the fastest growth in terms of waste generation are Sub-Saharan Africa, South Asia, and the Middle East and North Africa. An estimated 15 million people worldwide are involved in informal waste recycling, and 11 billion tonnes of solid waste are generated each year (Kaza et al., 2018). This challenge is compounded by weak sanitation infrastructure, policies as well as enforcement of laws to the latter (Saghir \& Santoro, 2018).

In Ghana approximately 13,000 tonnes of these wastes are generated every day, out of which an estimated $22 \%$ is left uncollected and untreated within communities. Accra and Tema generate about 3000 tonnes/day (Samwine et al., 2017).

Municipal solid waste in Ghana is typically an unsegregated mixture of food waste, health care or medical waste (both hazardous and non-hazardous), e-waste, plastics, agricultural waste, and other forms of hazardous and non-hazardous waste materials, generated by both private and commercial activities. The composition of solid waste typical for developing countries has an organic waste content averaging 61\%; however Miezah et al. (2015) reported 67\% of organic waste for Ghana, but that included paper. Recyclables including plastics, textiles, metals, glass, rubber and leather accounted for $22 \%$ in their study.

Figure 1 shows research findings of changes in the composition of solid waste in Ghana between 1998 and 2015 which compares favourably.

The composition of household waste shows that the possibility for the quantities of the dry fractions to be used for recycling is not enough to achieve the goal of $50 \%$ recycling rate. It is only when all recyclable fractions, including organic waste, are recycled at an optimum will these efforts yield a recycling rate of over $50 \%$ for all household waste. Neither organic waste nor dry materials recycling alone can reach the household recycling rate of $50 \%$ and a consensual effort incorporating all recyclable streams will be necessary (Hill et al., 2014).

The rate of waste generation in Ghana is $0.47 \mathrm{~kg} /$ person/day. Wastes that decompose (organics and papers) amount to $0.318 \mathrm{~kg} /$ person/day and the recyclables (metals, glass, textiles, leather and rubbers) which do not decompose to $0.096 \mathrm{~kg} /$ person/day. Inert and miscellaneous waste is $0.055 \mathrm{~kg} /$ person/day (Miezah et al., 2015).

Ghana depends heavily on landfills and open dumps. Landfill operations are most of the time un-engineered open-pit waste dumping with no leachate control, hardly any application of cover material and easily accessible to scavenging animals, rodents and other disease vectors. The Medium-Term National Development Policy Framework (MTNDPF) (2018-2021), states that solid waste management remains a big challenge in many places, with the quantity of solid waste properly disposed of reduced from $79 \%$ in 2014 to $70 \%$ in 2016. 


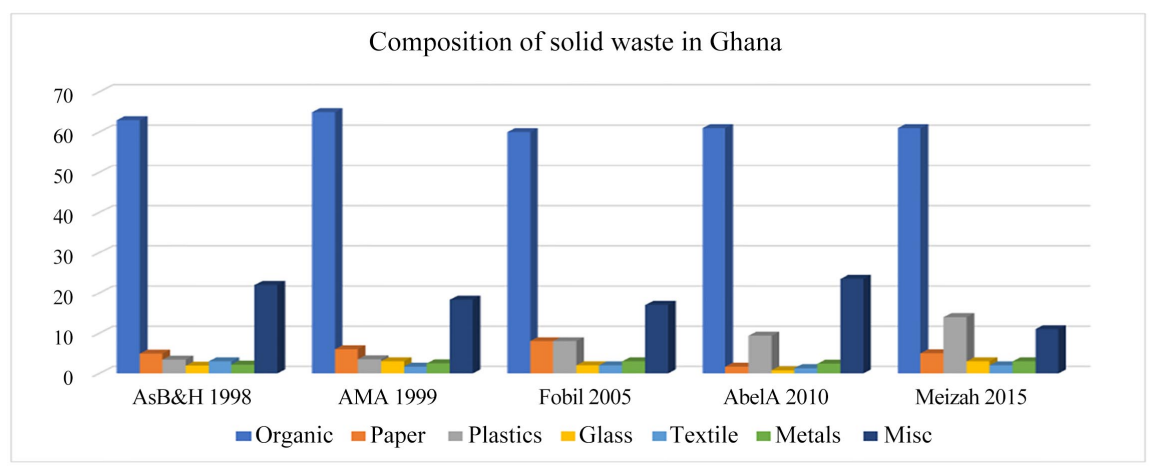

Figure 1. Composition of solid waste in Ghana (Gbeddy, 2019).

The main challenge facing environmental pollution control with emphasis on solid waste management is the weak institutional capacity for environmental management. This has resulted in poor coordination among the key government institutions and stakeholders responsible for the sector, poor waste management practices, poor consideration of waste pickers and their role in recycling, inability to sustain implementation of interventions from the lack of the necessary financial and technological resources and how enforcement of regulations are ineffectively done. Poor practices on the part of the population worsen the situation, with people engaging in open burning of all forms of waste and in some instances, creating illegal dumpsites.

Plastics are the predominant component of the recyclables especially polyethylene terephthalate (PET) bottles. Today's socio-economic activities demand that different types of plastics such as shopping bags, PET bottle, packaging, and for use as components in electronic appliances. This has shot global consumption of plastics up by 20 -fold - to 100 million tonnes in 2009 compared to 1950 (UNEP, 2009). Instead of polluting the environment through burning, plastics from municipal solid waste (MSW) can be separated and recycled. $3.0 \%$ of the MSW is made of metals which include waste aluminum cans.

Solid waste management is a major challenge for metropolitan, municipal and district assemblies (MMDAs). The responsibility for waste management lies with local authorities (mainly municipalities). The work of the informal waste pickers is described as "poor and unregulated" and as something that is counterproductive to effective urban waste collection and recycling is overlooked (Acuto, 2014).

The United Nations Environmental Programme refers to waste pickers as the "invisible environmentalists" of the world. Waste pickers depend on collecting recyclable and other materials from the streets and landfills for their livelihoods (Gutberlet et al., 2018). Although operating informally, waste pickers are responsible for the recycling of as much as $50 \%$ of the plastic waste in the world (UNEP, 2013). Waste pickers are people who make a living on waste in an informal way-i.e. they have no contract and a regular source of income.

Municipal solid waste contains hazardous substances (Robinson, 2009). There are materials that are valuable and that can be recycled (Antonis Mavropoulos, 
2015). In low- and middle-income countries, a larger part of the waste management is carried out by informal waste pickers. They collect waste on the streets or in households, sort out materials in a dumpsite and sell recyclables to middlemen. They do not work for the institutions in charge of waste management neither do they work for waste recycling companies. They therefore, depend on the number of recyclables they are able to recover or on the number of materials they are able to sell.

The International Labour Organisation (ILO) defines informal waste workers as "individuals or small and micro-enterprises that intervene in waste management without being registered and without being formally charged with providing waste management services" (GIZ, 2011). It has been estimated by the World Bank that about $2 \%$ of the urban population in developing countries makes their livelihood through the informal waste sector (IWS). The IWS provides income to at least 15 million people worldwide and its economic impact is several billions of US dollars a year (Walker, 2008).

Solid waste management involves storage, collection, transport, treatment, processing and disposal (Singh et al., 2014). Informal waste pickers are active in solid waste collection and recovery all over the world. They work as waste collectors, collectors of recyclable materials in the streets or as waste pickers on transfer stations and dumpsites.

The private sector (including waste pickers) has become more and more involved in waste management operations with $80 \%$ of waste services in the 254 Metropolitan, Municipal and District Assemblies (MMDAs) of Ghana are provided by the private sector. Many people are engaged in the collection of recyclable waste. After collection and cleaning, the recyclables are sold to middle men who transport them to one of the recycling plants. Even though Ghana has 35 institutionalised treatment plants, only $11 \%$ or 4 plants are operational for the treatment of waste (Abalo et al., 2018).

Waste pickers are men, women and children who get their livelihood from the sales of recyclables that they recover solid waste be it in households, offices, markets, industries, construction sites and on dumpsites (Awopetu et al., 2014). Most waste pickers work at landfill or dumpsites which serve as a repository of the solid waste generated by the cities. They are mostly permanent at these sites with a few of them migrating from decommissioned to commissioned sites. Others move from place to place, collecting materials from factories, offices, stores, schools, hospitals and residential areas. Others work at canals, and rivers where people dump their refuse (Bernstein, 2004).

Waste pickers are not part of the policy on waste management in Ghana and the aim of this study is to look at their role in the solid waste management system and how they can be integrated into the solid waste management system. The purpose of this study is to assess the role of waste pickers in the recycling industry and how they can be integrated into the solid waste management system. Waste pickers work within these sites by collecting recyclable materials that are sold in local markets Add here a clear description of the aims and scope of your study. 


\section{Methodology}

\section{The study dumpsites}

Three dumpsites, Kpone, Pantang and Nsumia (see Figure 2 and Figure 3) were considered in this study. These dumpsites were selected based on the fact that they are the repository of municipal solid waste for Accra and Tema. The Kpone landfill site (a), the Pantang dumpsite (b) and Nsumia dumpsite (c). In general, the selection of the study positions was to ensure the comparability of the results.

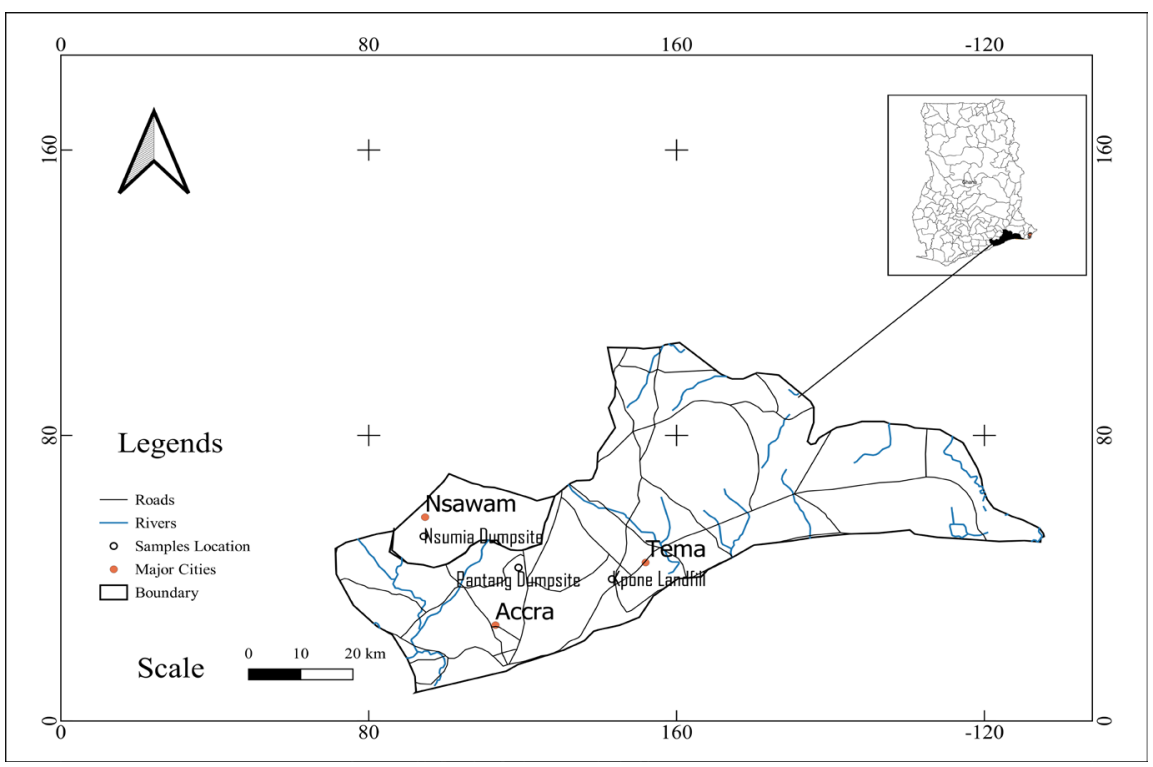

Figure 2. A map showing the three dumpsites.

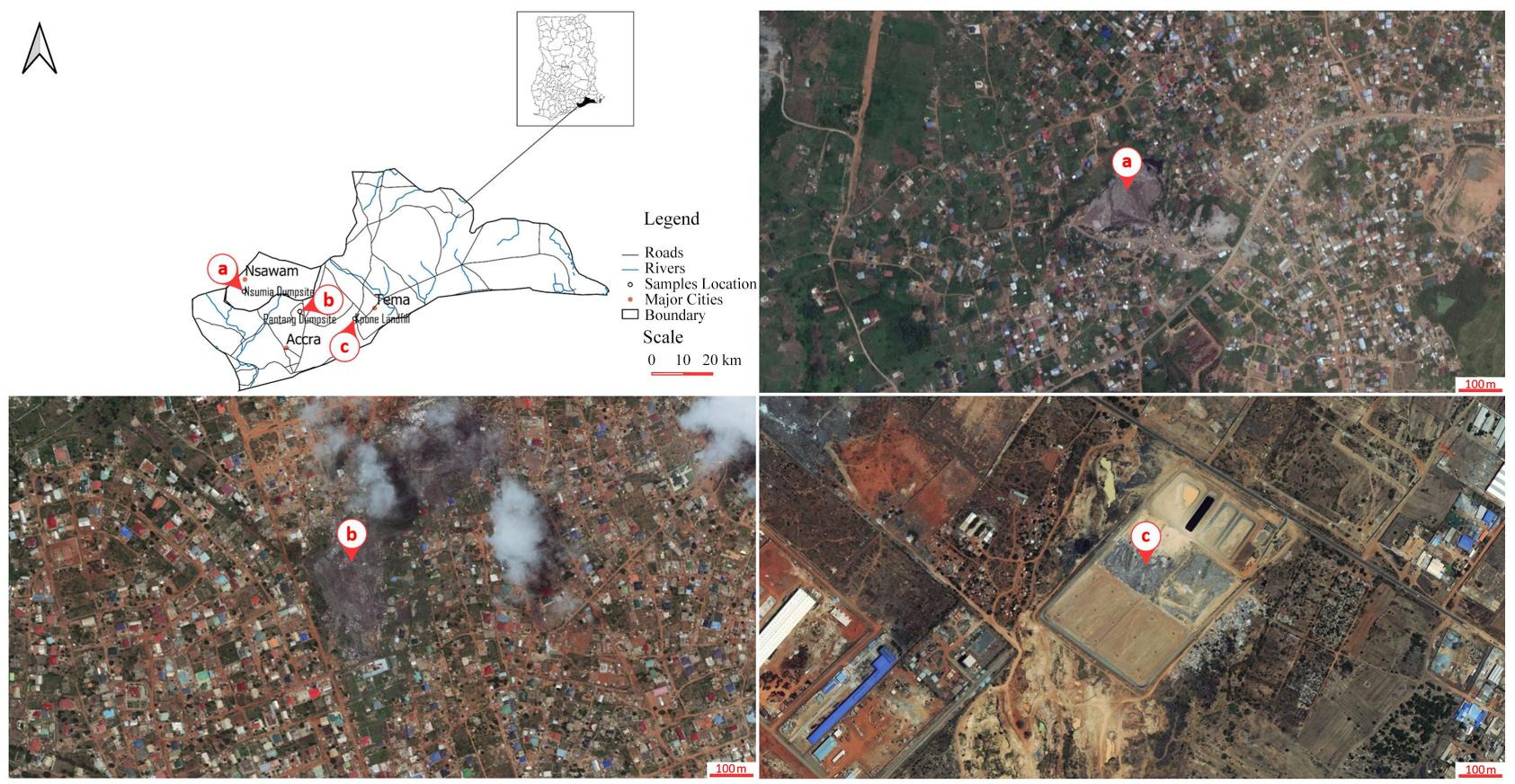

Figure 3. A satellite map showing the three dumpsites. 
The Kpone engineered landfill is located about $5 \mathrm{~km}$ northeast of the Tema city center and $37 \mathrm{~km}$ from the central business district of Accra. It serves the people of Accra and Tema. The site is located within the geographical boundaries of the Kpone Katamanso Municipal Area. The municipality lies within the dry equatorial climatic zone and has a bi-modal rainfall pattern. The mean annual rainfall ranges from $811 \mathrm{~mm}$ to $1320 \mathrm{~mm}$. Annual average temperatures ranges from $21.7^{\circ} \mathrm{C}$ in August and $31.1^{\circ} \mathrm{C}$ in January and February. The landfill site designed to have a daily capacity of 350 tonnes averagely was handling 2500 tonnes of waste daily until Nsumia dumpsite came to the rescue. It is operated by Waste Landfills Ghana Limited a subsidiary of Jospong Group of Companies.

The Pantang dumpsite is located about $10 \mathrm{~km}$ from the central business district of Accra in the Ga East Municipality. It served the people of Accra. It is located at the northern part of Greater Accra Region. The municipality lies in the savannah ecological zone and has a bi-modal rainfall pattern. The mean annual rainfall ranges from $790 \mathrm{~mm}$ to $1288.1 \mathrm{~mm}$. Annual average temperature ranges from $25.1^{\circ} \mathrm{C}$ in August and $28.4^{\circ} \mathrm{C}$ in January and February. It was the dumpsite that had a daily capacity of between 800 and 1000 tonnes until it was decommissioned in January, 2019. It is operated by Waste Landfills Ghana Limited a subsidiary of Jospong Group of Companies.

Nsumia dumpsite is located about $28 \mathrm{~km}$ from the central business district of Accra in the Akuapem South Municipality in the Eastern region off the Accra Nsawam highway. It serves the people of Accra, Nsawam and its environs. The mean annual rainfall ranges from $790 \mathrm{~mm}$ to $1288.1 \mathrm{~mm}$. Annual average temperature ranges from $25.1^{\circ} \mathrm{C}$ in August and $28.4^{\circ} \mathrm{C}$ in January and February. It has a capacity of about 680,000 tonnes. The site receives an average of 800 tonnes of municipal solid waste and domestic waste from Accra and Nsawam daily but has a daily capacity of 1000 tonnes to ease the pressure on the Kpone dumpsite which was receiving about 2500 tonnes of waste a day. The facility served as an alternative solid waste dumpsite for residents particularly in western Accra and Nsawam. It is operated by Waste Landfills Ghana Limited a subsidiary of Jospong Group of Companies.

\section{Research design}

A mixed-methods approach was used for this research. It consists of collecting, analysing and mixing both quantitative and qualitative data at some stage of the research process within a single study to understand the research problem more completely (Creswell \& Tashakkori, 2007).

The approach involves interviews and questionnaires built on previous research in the field, such as the study of C. (Rinie) Schenck \& Blaauw (2011) and R. Schenck \& Blaauw (2011). An adapted version was also used in a study by J. M. M. Viljoen, C. J. Schenck, \& Blaauw (2012) on the street waste pickers in South Africa. The findings were integrated into the analytical phase of the study (Mbekeni \& Phiri, 2019). Both numerical and text-based information were concurrently collected. The questionnaires, consisting of quantitative and qualitative questions were developed, piloted and used, see Appendix. 
In addition to interviews and the administration of questionnaire, desk reviews of documentation, site visits, observations and measurements were applied. The questionnaire was administered over a period of two months. Its contents were divided into four thematic areas. The areas of specific interest for this study are parts 2 and 3, i.e. "waste pickers, their roles and mode of work in resource recovery" and "waste fraction recovery, economic benefits to waste pickers and support from proceeds", respectively.

Part two of the questionnaire was to find out if the waste pickers have had any prior training in a different job. The reasons why they chose to pick waste fractions and to find out if they have job security. Part 3 was to find out the number of days that they work on the dumpsites-related to exposure to hazards evaluation, the waste fractions they recover, the quantities they recover and the money they make out of it.

Secondary data on the daily quantities of solid waste dumped at the landfill site were collected from the Tema Metropolitan Assembly (TMA) manager at the landfill site and compared with the quantities recovered by the waste pickers over a one-month period. Two site reconnaissance visits each were undertaken to the three dumpsites to have firsthand information on the activities of the waste pickers and the general operations of the sites.

\section{Sampling Size and Procedure}

A random sampling procedure was used. A sample size of 200 waste pickers out of 345 waste pickers across the 3 municipal dumpsites who volunteered to be part of the study were selected and involved in the survey. Other stakeholders and frontline actors involved in the operations and maintenance management, regulation and enforcement management at the dumpsites were an integral part of this study.

Of the 200 waste pickers selected, 120 came from Kpone, 20 from Pantang and 60 from Nsumia. Some of the pickers have moved from Pantang to the other two especially Kpone as a result of the ban on big trucks dumping there.

\section{Ethical consideration}

Formal permission was sought from the operators of the dumpsites Waste Landfills Ghana Limited and the three Assemblies (Tema Metropolitan, Ga East Municipal and Akuapem South Municipal Assemblies). An informal consent was also sought directly by meeting with the various waste pickers to willingly volunteer to be part of this study. It entailed the purpose of the study, benefits, privacy/confidentiality and conflict of interest. Participation was absolutely voluntary and each subject had the opportunity to participate or opt out at any point in the course of the survey.

\section{Results}

Table 1 shows the shares of waste pickers who volunteered to answer the questionnaire from the three dumpsites. Table 2 shows the number of days in a week that the waste pickers work on the dumpsites with a time weighted average of 5.6 days. In Table 3 the various waste fractions and the number of pickers who re- 
cover them are shown. The waste fractions that are recovered more are plastics followed by paper.

Table 4 shows the period that a waste picker takes to gather a tonne of a waste fraction. As it is now all of them pick any valuables they come across and pack them till they have had enough to sell to the middle men ${ }^{1}$. Mobile phone and television motherboards are sold as and when they get them. Beverage cans are also collected. The most abundant of the valuables are plastics and paper.

It takes less than a week to gather a tonne of plastics mainly polyethylene terephthalate (PET) bottles. Paper and aluminum can take between one and two weeks to gather a tonne. Table 5 shows the quantity of the various waste fractions that each picker gathers within a week. In Table 6 the designed waste is supposed to be dumped and what is actually dumped over a five-year period.

Kpone is the only dumpsite with a weighing bridge but it is faulty. The supervisors therefore use the volume of the trucks to approximate the quantity of waste received at the dumpsites. There are no weigh bridges at Nsumia and Pantang so the volume of waste deposited daily is an approximation by the managers of the dumpsites. The tonnage of the trucks is used in the approximation. Between the two dumpsites an average of 800 tonnes of waste is sent there daily until Pantang was closed down permanently in January 2018 as shown in Table 7.

On the average 1700 tonnes of waste is collected and dumped at the three dumpsites daily. From Table 5 each waste picker is able to gather recyclables up to $230 \mathrm{~kg}$ per week. It means each of the waste pickers collect valuables up to 41 $\mathrm{kg}$ a day. The three dumpsites have a total of 345 (three hundred and forty-five) active scavengers at the time of the study who work between four and seven days a week all year round with a time weighted average of 5.6 days.

Table 1. Number of waste pickers interviewed.

\begin{tabular}{cccc}
\hline Landfill/dumpsite & $\begin{array}{c}\text { Number of waste pickers } \\
\text { interviewed }\end{array}$ & $\begin{array}{c}\text { Estimated number of } \\
\text { waste pickers on site }\end{array}$ & $\begin{array}{c}\text { \% of waste pickers } \\
\text { interviewed }\end{array}$ \\
\hline Kpone & 120 & 200 & 60 \\
Nsumia & 60 & 120 & 50 \\
Pantang & 20 & 25 & 80 \\
Total & 200 & 345 &
\end{tabular}

Table 2. Number of days in a week waste picker work on the various dumpsites.

\begin{tabular}{ccccc}
\hline Days/week & Kpone & Nsumia & Pantang & Total \\
\hline 4 & 15 & 2 & - & 17 \\
5 & 20 & 18 & 12 & 50 \\
6 & 65 & 34 & 8 & 107 \\
7 & 20 & 6 & - & 26 \\
\hline
\end{tabular}

Note: time weighted average (TWA) of number of days per week waste pickers work is 5.6 days.

${ }^{1}$ They are businessmen who buy the recyclables from the waste pickers and gather them on the dumpsites until they have enough to sell to the industries. 
Table 3. Number of waste pickers who recover the various waste fractions.

\begin{tabular}{ccccc}
\hline Waste fraction & Kpone & Nsumia & Pantang & Total \\
\hline Metals & 14 & 3 & 1 & 18 \\
Plastics & 59 & 36 & 12 & 107 \\
E-waste & 20 & 7 & 3 & 30 \\
Paper & 18 & 9 & 3 & 30 \\
Copper & 9 & 5 & 1 & 15 \\
Cans & 120 & 60 & 20 & 200 \\
Total & 120 & 60 & 20 & 200 \\
\hline
\end{tabular}

Table 4. Average recovery rate of waste pickers to be able to collect a tone.

\begin{tabular}{|c|c|c|c|c|}
\hline Waste fraction & $<$ than a week & $1-2$ weeks & 3 - 4 weeks & $>5$ weeks \\
\hline Metals & & & $\mathrm{x}$ & \\
\hline Plastics & $\mathrm{x}$ & & & \\
\hline E-waste & & & & $\mathrm{x}$ \\
\hline Paper & & $\mathrm{x}$ & & \\
\hline Copper & & & & $\mathrm{x}$ \\
\hline Cans & & $\mathrm{x}$ & & \\
\hline
\end{tabular}

Table 5. Average weekly recovery of waste fractions by a Waste Picker.

\begin{tabular}{cc}
\hline Waste fraction & $\begin{array}{c}\text { Average quantity recovered in a week }(\mathrm{kg}) \\
\text { by each waste picker in the category }\end{array}$ \\
\hline Metals (18) & 15 \\
Plastics (107) & 120 \\
E-waste (phones and TV boards) (30) & 5 \\
Paper (30) & 30 \\
Copper (15) & 10 \\
Cans (200) & 50 \\
\hline
\end{tabular}

Table 6. Comparison of the design ${ }^{*}$ and the actual waste volumes.

\begin{tabular}{ccc}
\hline & Average daily waste volume dumped at Kpone landfill \\
\hline Year & Projected design waste amount (tonnes) & Actual waste amount (tonnes) \\
\hline 2014 & 314 & 962 \\
2015 & 325 & 833 \\
2016 & 337 & 845 \\
2017 & 351 & 921 \\
2018 & 367 & 960 \\
$2014-2018$ average & 339 & 904 \\
\hline
\end{tabular}

${ }^{\star}$ The amount of waste that was to be taken up by the landfill per how it was designed. 
Table 7. Pantang and Nsumia average daily intake between 2014 and 2018.

\begin{tabular}{ccc}
\hline Year & Pantang & Nsumia \\
\hline 2014 & 600 & 200 \\
2015 & 500 & 300 \\
2016 & 150 & 650 \\
2017 & 80 & 720 \\
2018 & - & 800 \\
$2014-2018$ average & 266 & 534 \\
\hline
\end{tabular}

Kpone has a total of 200 waste pickers with an average waste dumped as 904 tonnes per day between 2014 and 2018. Nsumia has a total of 120 waste pickers with an average waste dumped as 534 tonnes per day between 2014 and 2018 and Pantang had a total of 25 waste pickers with an average waste dumped as 266 tonnes per day for the same period. Estimated valuables collected by the waste pickers at the dumpsites for the year can be deduced from their weekly recovery to give their contribution towards the life span of the dumpsites (Figure 4).

\section{Discussion}

The recycling industry generate revenues and jobs for a larger number of people in the world today. It relies on the informal recovery of materials from waste scavenging. $1 \%$ of the urban population which makes up to 15 million worldwide, with an economic impact on several millions who are dependent on them.

Emphasis was placed on the Kpone landfill site as the other two dumpsites do not have data to support the role waste pickers play in the waste management system. Of the three dumpsites it is only Kpone that has a fence around it even though parts are broken. The total waste volume in December 2018 after 6 years of operation was $1,771,493$ tonnes. This corresponds to a projected design waste placement for a 13-year period. This implies that the landfill will not last the projected number of years (TMA landfill manager).

There is a significant presence of waste pickers at the Kpone engineered landfill and Nsumia dumpsite. At Pantang a lot of the scavengers have migrated to the other two dumpsites as a result of less activity. The scavengers at Kpone belong to the Tema Landfill Recyclable Waste Pickers Association. This association was formed with the help of the NGO Women in Informal Employment: Globalizing and Organizing (WIEGO). The waste pickers at Pantang and Nsumia do not have such an association.

This means that the waste pickers need to be more organized them and integrated formally into the waste management system and more plastic recycling industries established so that the production chain becomes sustainable and helps contribute to the circular economy. 


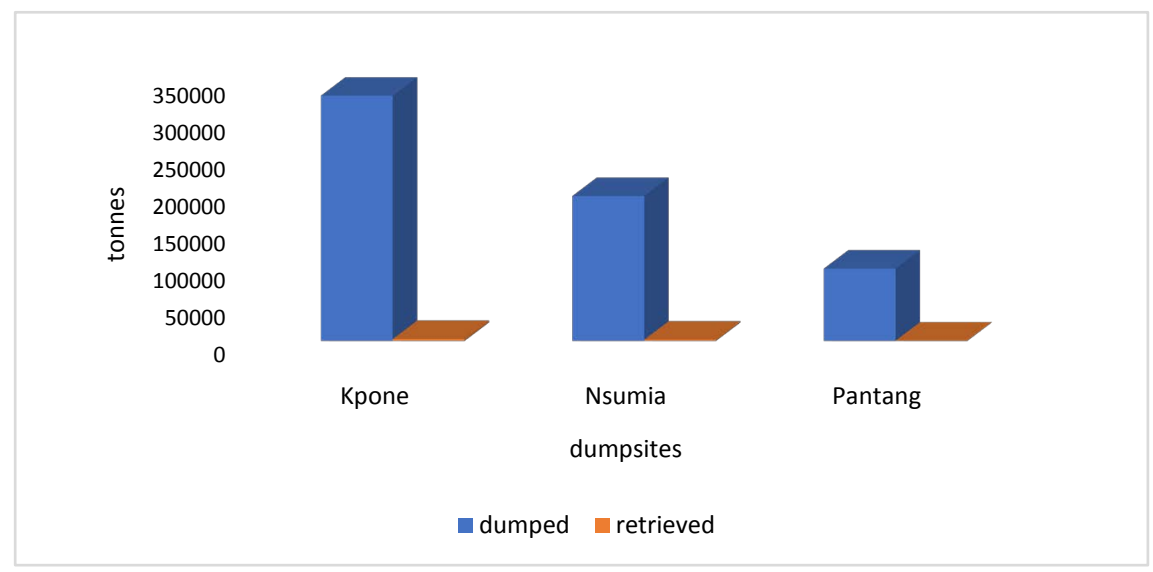

Figure 4. Waste dumped compared to valuables retrieved at the three dumpsites per annum.

The demand for aluminum is expected to grow from 37 million tonnes in 2016 to 70 million tonnes in 2020 . This will mean there will be pressure on the raw material for the production of aluminum. Recycling aluminum cans requires only about $5.0 \%$ of the energy required to process bauxite to produce aluminum (Abalo et al., 2018).

A total of 4123 tonnes of waste is recovered annually by waste pickers at the three dumpsites. This estimated recovered recyclables is equivalent to about 2.4 times the average daily waste dumped at the dumpsites for the past five years. The type of waste recovered was dominated by different kinds of plastics. In as much as their contributions may seem insignificant, a holistic radical change in our solid waste management system and practices will improve the recovery rates of the waste pickers to boost the recycling industry.

Waste pickers play an important role in waste segregation in cities all over the world. In fact, in some developing countries, these informal employees are solely responsible for waste segregation and collection. In Ghana, they are the only ones that do waste segregation; however, the total amount of segregated waste is probably low less than $1 \%$ of the total waste dumped at the dumpsites. This is an indication that there is the need for drastic changes in our waste management system. Additionally, they play a role by guiding valuable materials to the recycling chain, thereby reducing the quantities of waste disposed. In troubled economies, waste picking is the source of livelihood for the marginalized and vulnerable in society.

Recycling one tonne of plastic saves $5.74 \mathrm{~m}^{3}$ of landfill space and save cost of collection and transportation (Nizami et al., 2017). Considering that most of the materials recovered were plastics, using the volume of space indicated by Ahmad and the estimated tonnes of waste recovered, about $23,666.02 \mathrm{~m}^{3}$ of space at the dumpsites are freed annually due to the work of the waste pickers.

To boost the recycling industry in Ghana, there should be source separation and diversion of organic waste which is the bulk of our waste fraction for composting. This can reduce substantially the volume of waste at the dumpsites the- 
reby extending the life of disposal sites. This will help prevent pollution and generation of methane a greenhouse gas (GHG) at the dumpsites.

Policy makers must be interested in improving the wellbeing of waste pickers and analysts interested in the nature of the informal economy. Only supportive policies can unlock the development potential of the informal recycling sector. Recovery Activities should be legalized and the efforts of the waste pickers should be supported for them to get organized. Waste picker Organisations should be considered as potential partners by promoting their participation in public private partnerships (PPPs).

If waste pickers get organized and supported, there will be job creation which will lead to poverty reduction. It will lead to the conservation of natural resources, protect the environment. It also extends the life of disposal sites.

In the course of their work, they contribute immensely towards environmental protection and management and also the economy precisely the circular economy by reincorporating whatever they have recovered into the economy/s production system (Abalo et al., 2018).

They are victims of social stigmatisation and they belong to socially vulnerable groups, such as migrants, women, children, the elderly, the disabled, and the unemployed. While informal workers are recognised as important for waste management in the majority of cities of the Global South, their activities are generally labour-intensive, low-tech, low-paid, often managed autonomously or in the family (Olanrewaju \& Oyebade, 2019).

In general, questionnaire designs limit the use of extensive probing by the interviewer and rarely use unstructured or open-ended questions. Consequently, the data might easily lack the detail or depth that the researcher desires for addressing the initial research problems (Wilson et al., 2012). Another limitation of questionnaires is that it can be difficult to know whether the selected respondents are being truthful. The effectiveness of questionnaire could be hindered by the respondents' insufficient knowledge or understanding of the questions that were posed to them (Otokiti, Adejumo, \& Olateju, 2010).

\section{Conclusion}

Waste picking is a source of livelihood for the working poor and vulnerable. The informal waste pickers make relevant contributions to cities in terms of aesthetics. Government policies and public perceptions about waste pickers are based on misconception that largely ignore their contribution to waste management and the environment.

Waste-pickers or their organisations should be integrated into the formal solid waste management system. Solid waste management planners should introduce waste segregation and involve waste-pickers in the collection of recyclables from households.

Sensitization and public education by municipal authorities should be embarked on to remove or minimize the stigmatization and marginalization that 
waste-pickers suffer and the role they play in the solid waste cycle. Waste-pickers lack basic amenities like access to health services, access to education for their children and themselves.

There should be revision and improvement in waste management policies as well as technical reorganization and orientation of the dumpsites so as to include plants for waste separation that will make recycling of materials very efficient as practiced in Slovenia.

\section{Acknowledgements}

My gratitude goes to the supervisors and managers of three dumpsites for their support during the course of this study. A big thank you goes to all the waste pickers who were part of this study.

\section{Conflicts of Interest}

The authors declare no conflicts of interest regarding the publication of this paper.

\section{References}

Abalo, E. M., Peprah, P., Nyonyo, J., Ampomah-Sarpong, R., \& Agyemang-Duah, W. (2018). A Review of the Triple Gains of Waste and the Way Forward for Ghana. Journal of Renewable Energy, 2018, Article ID: 9737683. https://doi.org/10.1155/2018/9737683

Acuto, M. (2014). Everyday International Relations: Garbage, Grand Designs, and Mundane Matters. International Political Sociology, 8, 345-362. https://doi.org/10.1111/ips.12067

Awopetu, M. S., Awopetu, R. G., Sample, E. D., Olufiropo, A. O. C., Awokola, S., Fullen, M. A., Booth, C. A., \& Hammond, F. N. (2014). Municipal Solid Waste Management and the Role of Waste. International Journal of Educational Research, 2, 1-12.

Bernstein, J. (2004). Toolkit: Social Assessment and Public Participation in Municipal Solid Waste Management (pp. 1689-1699). Urban Environment Thematic Group.

Chabuk, A., Al-Ansari, N., Hussain, H. M., Knutsson, S., \& Pusch, R. (2015). Present Status of Solid Waste Management at Babylon Governorate, Iraq. Engineering, 7, 408-423. https://doi.org/10.4236/eng.2015.77037

Creswell, J. W., \& Tashakkori, A. (2007). Developing Publishable Mixed Methods Manuscripts. Journal of Mixed Methods Research, 1, 107-111.

Douti, N. B., Abanyie, S. K., Ampofo, S., \& Nyarko, S. K. (2017). Solid Waste Management Challenges in Urban Areas of Ghana: A Case Study of Bawku Municipality. International Journal of Geosciences, 8, 494-513. https://doi.org/10.4236/ijg.2017.84026

Gbeddy, P. (2019). In-Depth Analysis of Municipal Solid Waste Collection System in Ghana (Case Study: Accra Municipality).

GIZ (2011). Recovering Resources, Creating Opportunities.

Gutberlet, J., Mohammad, S., \& Uddin, N. (2018). Household Waste and Health Risks Affecting Waste Pickers and the Environment in Low- and Middle-Income Countries. International Journal of Occupational and Environmental Health, 23, 299-310.

Hill, A. L., Dall, O. L., \& Andersen, F. M. (2014). Modelling Recycling Targets: Achieving 
a 50\% Recycling Rate for Household Waste in Denmark. Journal of Environmental Protection, 5, 627-636. https://doi.org/10.4236/jep.2014.57064

Kaza, S., Yao, L. C., Bhada-Tata, P., \& Van Woerden, F. (2018). What a Waste.

Mavropoulos, A. (2015). ISWA ISWA STC Chair.

Mbekeni, L., \& Phiri, A. (2019). South African Unemployment in the Post-Financial Crisis Era: What Are the Determinants? Munich Personal RePEc Archive (MPRA) Paper No. 94159.

Miezah, K., Obiri-danso, K., Kádár, Z., Fei-Baffoe, B., \& Mensah, M. Y. (2015). Municipal Solid Waste Characterization and Quantification as a Measure towards Effective Waste Management in Ghana. Waste Management, 46, 15-27.

https://doi.org/10.1016/j.wasman.2015.09.009

Nizami, A. S., Rehan, M., Naqvi, M., Ouda, O., Shahzad, K., Syamsiro, M., Waqas, M., Miandad, R., Asam, Z. U. Z., \& Mohammad Ismail, I. (2017). Energy, Economic and Environmental Savings by Waste Recycling: A Case Study of Madinah City. Energy Procedia, 142, 910-915. https://doi.org/10.1016/j.egypro.2017.12.146

Olanrewaju, O. O., \& Oyebade, D. (2019). Environmental Menace of Plastic Waste in Nigeria: Challenges, Policies and Technological Efforts. Transition Pathways to Sustainable Development Goals: Integrated Landscape Approach, Economic Well Being and Inclusive Climate Resilience, Akure, June 2019, 322.

https://www.researchgate.net/publication/335989265

Otokiti, O. S., Adejumo, G. O., \& Olateju, I. (2010). Contemporary Statistical Methods. Ota, Ogun State: Vantage Publication Company.

Robinson, B. H. (2009). E-Waste: An Assessment of Global Production and Environmental Impacts. Science of the Total Environment, 408, 183-191.

https://doi.org/10.1016/j.scitotenv.2009.09.044

Saghir, J., \& Santoro, J. (2018). Urbanization in Sub-Saharan Africa. Meeting Challenges by Bridging Stakeholders (pp. 1-7). Washington DC: Center for Strategic \& International Studies.

Samwine, T., Wu, P., Xu, L., Shen, Y., Appiah, E., \& Yaoqi, W. (2017). Challenges and Prospects of Solid Waste Management in Ghana. International Journal of Environmental Monitoring and Analysis, 5, 96-102. https://doi.org/10.11648/j.ijema.20170504.11

Sankoh, F. P., Yan, X., \& Tran, Q. (2013). Environmental and Health Impact of Solid Waste Disposal in Developing Cities: A Case Study of Granville Brook Dumpsite, Freetown, Sierra Leone. Journal of Environmental Protection, 4, 665-670.

https://doi.org/10.4236/jep.2013.47076

Schenck, C. (Rinie), \& Blaauw, P. (Derick) (2011). Living on What Others Throw Away: An Exploration of a Socio-Economic Circumstances of People Collecting and Selling Recyclable Waste.

Schenck, R., \& Blaauw, P. F. (2011). The Work and Lives of Street Waste Pickers in Pretoria-A Case Study of Recycling in South Africa's Urban Informal Economy. Urban Forum, 22, 411-430. https://doi.org/10.1007/s12132-011-9125-x

Singh, G. K., Gupta, K., \& Chaudhary, S. (2014). Solid Waste Management: Its Sources, Collection, Transportation and Recycling. International Journal of Environmental Science and Development, 5, 347-351. https://doi.org/10.7763/IJESD.2014.V5.507

UNEP (2009). Developing Integrated Solid Waste Management Plan. Book 4.

UNEP (2013). Health and Safety Guidelines for Waste Pickers in South Sudan.

Viljoen, J. M. M., Schenck, C. J., \& Blaauw, P. F. (2012). The Role and Linkages of 
Buy-Back Centres in the Recycling Industry: Pretoria and Bloemfontein (South Africa). Acta Commercii, 12, 1-12. https://doi.org/10.4102/ac.v12i1.125

Walker, D. (2008). The World's Scavengers: Salvaging for Sustainable Consumption and Production. Development in Practice, 18, 823-824.

https://doi.org/10.1080/09614520802387304

Wilson, D. C., Rodic, L., Scheinberg, A., Velis, C. A., \& Alabaster, G. (2012). Comparative Analysis of Solid Waste Management in 20 Cities. Waste Management and Research, 30, 237-254. https://doi.org/10.1177/0734242X12437569 